\title{
LA RETÓRICA DEL VERSO: APROXIMACIONES A LA MÉTRICA DESDE LA RETÓRICA
}

\author{
Rosa M. a Aradra SÁNChez
}

\section{Resumen:}

Métrica y poética son disciplinas tradicionalmente emparentadas. En el panorama general de los estudios literarios, la retórica ofrece también un interesante campo de análisis en relación con el verso, no siempre considerado. Este trabajo es un primer recorrido introductorio por algunas de las incursiones teóricas de la retórica en el ámbito del verso, y su reflejo concreto en las distintas fases de elaboración del discurso persuasivo, especialmente en las figuras de la elocución.

Palabras clave:

Métrica, Retórica, Elocutio, Persuasión, Ritmo, Prosa.

\section{Abstract:}

Metrics and Poetics are two disciplines traditionally interconnected. In the general context of literary studies, Rhetoric offers, also, an interesting but not always considered field for analysis in relation to vers. This paper is a preliminary approximation that examines the relationship between rhetoric and versification. Moreover, it presents how the different parts of rhetoric can tackle vers, specially the figures of classical elocutio.

Key words:

Metrics, Rhetoric, Elocutio, Persuasion, Rhythm, Prose. 

$\mathrm{N}$ o resulta extraño encontrar consideraciones sobre las relaciones entre métrica y poética en muchos manuales que tienen por objeto el estudio de la literatura y sus formas, pero sí resulta menos frecuente hallar referencias explícitas a las conexiones entre métrica y retórica.

En cuanto a lo primero, basta recordar que el estudio del verso y del ritmo se juzga connatural a la esencia de la poesía desde los orígenes mismos de la reflexión literaria. Ya Aristóteles al comienzo de su Poética señalaba que, aunque no fueran todos iguales, los llamados poetas se valían por lo común del verso, y géneros tan distintos como la epopeya, la tragedia, la comedia, el ditirambo, la aulética o la citarística, compartían el ritmo, la palabra y la armonía, combinados o no ${ }^{1}$.

El hecho de que la retórica se vinculara desde sus orígenes a la prosa, mientras la poética acogía el estudio de las composiciones en verso, fundamentó estas conexiones. Sin embargo, la relación entre retórica y métrica no resulta tan sorprendente si nos detenemos un poco en el tema. Quizá el referente inmediato en el que primero pensamos sea el de la elocutio, esa parte de la retórica asumida por la poética para explicar el lenguaje literario y el poético en particular. Pero no es ese el único punto de contacto, de intereses compartidos y de reciprocidades metodológicas. Hay todo un abanico de encuentros y reencuentros históricos y actuales de gran interés, desde la atención a determinados recursos y figuras de mayor uso en el verso a otras muchas posibilidades que las restantes partes de la retórica ofrecen al estudio y análisis de la versificación.

${ }^{1}$ Cf. Aristóteles: Poética, en Aristóteles, Horacio, Artes poéticas. Ed. de Aníbal González, Madrid: Taurus, 1987, 1447a y 1447b. 
En este trabajo me propongo hacer un breve recorrido por las partes tradicionales de la retórica como un primer acercamiento teórico a las concomitancias y conexiones entre ambos campos, $\mathrm{y}$, de forma paralela, apuntar algunas realizaciones concretas que vinculan en la práctica retórica y métrica, con especial atención a la elocución. Se trata de una aproximación general que por su amplitud justifica investigaciones ulteriores desde diferentes campos y perspectivas.

De manera general pensamos en la métrica como la "disciplina que se encarga de estudiar las normas y principios que organizan la versificación, es decir, las reglas por las que se rige el verso, sus clases y combinaciones" ${ }^{\text {. }}$. En el otro lado, la retórica es el ars bene dicendi del que habló Quintiliano y la técnica que se ocupa ampliamente del discurso persuasivo. "Persuadir" significa, según la RAE: "Inducir, mover, obligar a alguien con razones a creer o hacer algo".

Tal vinculación nos haría preguntarnos por la capacidad persuasiva del verso, que, más allá de su posible peso argumentativo, enlazaría con los mecanismos generales de la persuasión literaria y mostraría de qué manera las fronteras entre verso y prosa -oratoria o literaria- nos adentran en fructíferas zonas de confluencia y apuntan la rentabilidad de antiguos planteamientos para enfoques modernos en el tratamiento de la prosa y el verso. La perspectiva retórica trasciende desde este punto de vista lo meramente argumentativo para presentarse como una disciplina de amplio enfoque textual, que afecta tanto a los procesos de creación y recepción como a los de crítica y análisis.

Históricamente son muchos los puntos en común de estas disciplinas. La retórica clásica, estrechamente marcada por una cultura predominantemente oral y por un enfoque político, compartió con la poesía esa capacidad a la que hemos aludido de influir en unos receptores haciendo cambiar de opinión al auditorio, de hechizarle a través de la palabra y despertar su admiración $^{3}$. Es cierto que la finalidad de ambos discursos, el retórico

ㄱomínguez Caparrós, José: Métrica española. Madrid: Síntesis, 1993, p. 15.

${ }^{3}$ Cf. Lopez Eire, Antonio: Retórica clásica y teoría literaria moderna. 
y el poético-literario, no es la misma, y que esto determina con claridad sus diferencias, pero también es cierto que las transformaciones políticas, sociales y culturales pronto aproximaron sus planteamientos. La retórica se convirtió en la base de la formación humanística y sustituyó la orientación práctica de sus orígenes por la educativa. Tales circunstancias incidirán de lleno en una mayor atención al género epidíctico, aquel más próximo a los receptores, fines y medios de la literatura, frente a los hasta entonces privilegiados géneros deliberativo y judicial. Arranca de aquí la conocida literaturización de la retórica y el hermanamiento entre retórica y poética a través de la búsqueda, no tanto de la verdad filosófica, como del relativismo de la verosimilitud, del valor de lo emocional como elemento persuasivo, y del ritmo, que tan en cuenta tendrá Gorgias en el siglo v a. de C.

En este proceso la retórica empezó a vincularse en los primeros tratados medievales a otras disciplinas como la gramática y la dialéctica, en un contexto que da cabida a nuevas formas oratorias y en el que surgen sucesivamente las ars dictaminis (s. XI), las ars poetriae (s. XII) y las ars praedicandi (s. XIII). La gramática, que ya en tiempos de Quintiliano se consideraba una ciencia dividida en dos partes, la ciencia de hablar correctamente y la explicación de los poetas ${ }^{4}$, acogerá los estudios poéticos, el ars rhytmica (arte de la composición rítmica tanto en prosa como en verso) y el ars versificatoria en particular. Estas últimas abordarán con detalle el estudio de la sílaba, la cantidad vocálica, el ritmo, las formas y licencias poéticas, etc.

A lo largo de la historia los estudios sobre el verso han ido cambiando su ubicación fluctuando básicamente entre la gramática y la poética. Superada la convivencia conjunta de retórica y poética en la época medieval, hay un mayor deseo de clarificar sus límites coincidiendo con el interés por la Poética de Aristóteles en el Renacimiento ${ }^{5}$. Con los antecedentes del Marqués de Santillana

Madrid: Arco Libros, 1997, p. 23.

4 Cf. Quintiliano, M. F.: Institutionis oratoriae libri XII: Sobre la formación del orador, doce libros. Traducción y comentarios de Alfonso Ortega Carmona. Salamanca: Universidad Pontificia de Salamanca, 1997-2001, 5 vols., I, IV, 2. Vid. también Murphy, J. J.: La retórica en la Edad Media. Historia de la retórica desde San Agustín hasta el Renacimiento. México: F. C. E., 1986, p. 145 y ss.

5 Cf. Bobes, Carmen, Baamonde, Gloria, Cueto, Magdalena, Frechilla, 
o de Encina, se han destacado en la teoría literaria española los ejemplos de Herrera, el Pinciano, Carvallo, Cascales o, ya en el XVIII, Luzán, como prueba de la estrecha relación disciplinar que guardan métrica y poética; incluso encontramos tratados dedicados exclusivamente a la métrica, como los de Sánchez de Lima o Rengifo, que mantienen la denominación de "arte poética" 6 .

No es nuestra intención detenernos ahora en la historia de este proceso, pero sí destacar el hecho de que la métrica, sólidamente ligada a los tratados de poética, convive junto a la retórica en un gran número de preceptivas que desde principios del XIX consolidan la aparición en el mismo volumen de retórica y poética. Bajo la influencia del teórico escocés Hugo Blair y la adaptación que hiciera Munárriz de sus Lecciones sobre la Retórica y las Bellas Letras (1798-1801), textos tan reeditados y asentados en el ámbito académico como los Principios de Retórica y Poética (1805) de Sanchez Barbero, los Elementos de Retórica y Poética (1818) de Mata y Araujo o el conocido Arte de hablar en prosa y verso (1826) de Hermosilla, estarán en la base de la posterior conjunción entre retórica y poética hacia planteamientos teóricos globales en torno a una ciencia de la literatura ${ }^{7}$.

No extraña, pues, que sea en el Diecinueve cuando encontremos tratados con una mayor entidad teórica dedicados exclusivamente al verso en una tradición que arranca de Andrés Bello, Eduardo de la Barra y otros teóricos que publicaron trabajos independientes sobre métrica ${ }^{8}$.

Emilio y Marful, Inés: Historia de la teoría literaria, II, Transmisores, Edad Media, Poéticas clasicistas. Madrid: Gredos, 1998, p. 170 y ss.

${ }^{6}$ Una presentación histórica del lugar que ocupa la métrica en los estudios literarios, con especial atención a los siglos XVIII y XIX, se puede ver en el estudio de Dominguez Caparrós, José: Contribución a la historia de las ideas métricas en los siglos XVIII y XIX. Madrid: C.S.I.C., 1975, pp. 1-50, y del mismo autor: "La métrica en los estudios literarios". Epos, 1992, 8, pp. $245-261$, p. 245 y ss.

${ }^{7}$ Para más información sobre este aspecto remitimos a nuestro trabajo: De la Retórica a la Teoría de la literatura (siglos XVIII y XIX). Murcia: Servicio de Publicaciones de la Universidad de Murcia, 1997.

${ }^{8}$ Cf. Domínguez Caparrós, José: Contribución a la historia de las ideas métricas, cit. y Métrica española, cit., p. 21. 


\section{II}

Pero empecemos ya nuestro recorrido. Como avanzamos más arriba, la elocutio retórica es la fase de elaboración discursiva en la que vamos a encontrar una atención más definida a recursos directamente emparentados con el verso. Aunque la mayoría de los procedimientos del ornatus que estudia la elocutio clásica fueron muy pronto ejemplificados con textos literarios, tanto en prosa como en verso, no es menos cierto que algunos han mostrado una rentabilidad mucho mayor en la versificación; de hecho, algunos de ellos se estudian como "licencias métricas".

Me refiero a las llamadas por la retórica tradicional figuras de dicción y, como un tipo especial, a las figuras de metaplasmo, según la denominación que le diera Quintiliano. Se trata de procedimientos que afectan básicamente al significante, a la forma de la palabra, a la expresión lingüística, y que, como les sucede a las figuras de dicción en general, pierden su esencia cuando son traducidas. En el caso concreto de los metaplasmos estamos ante unas licencias en las que se permite la utilización de términos que la gramática considera incorrectos (barbarismos), lo que nos sitúa en un terreno entre gramática, retórica y métrica, que se refleja en la atención vacilante a estos fenómenos en los tratados 9 .

En el estudio de las figuras Lausberg sistematiza en cuatro los apartados clásicos, según los criterios genéricos de adición, supresión, cambio de orden y sustitución ${ }^{10}$. Como resultado de la aplicación de estas categorías contamos con diversas posibilidades de adición o supresión de fonemas o sílabas al principio, en medio o al final de una palabra, a las que se han de sumar otras posibilidades por cambio de orden de los elementos fónicos o sustitución de unos por otros, con independencia de su posición dentro de la palabra. Recordemos que en los metaplasmos por adición se habla de la prótesis (arrecoger por recoger), la epéntesis (Ingalaterra por Inglaterra) y la paragoge (felice por feliz); en los metaplasmos por supresión, dependiendo si el elemento

\footnotetext{
${ }^{9}$ Pujante, por ejemplo, en su reciente tratado de retórica, los menciona pero no los desarrolla. Cf. Pujante, David: Manual de retórica, Madrid: Castalia, 2003, pp. 236-237.

${ }^{10}$ Cf. Lausberg, Heinrich: Manual de retórica literaria. Madrid: Gredos, $1966-1968,3$ vols. [1960].
} 
suprimido está al principio, en medio o al final de la palabra, tenemos la aféresis (hora por ahora), la síncopa (muchismos por muchísimos) y la apócope (ídol por ídolo). Los otros metaplasmos serían por cambio de orden: la metátesis (displicina por disciplina), y por sustitución: antistecon (melecina por medicina).

Algunos de estos resultados, que en la lengua común son rechazados como vitia o vicios del idioma, son admitidos en el verso como licencias por ser rentables en el cómputo silábico los dos primeros grupos de metaplasmos, es decir, los que permiten la adición o supresión silábica según las necesidades del poeta.

Desde esa concepción amplia de la gramática a la que antes hemos hecho referencia, Antonio de Nebrija, que ya había considerado en su Gramática de la lengua castellana (1492) catorce tipos de metaplasmo, diferenciaba de forma muy clara los conceptos de lexis, barbarismo y metaplasmo según su grado de corrección, y mostraba la conexión entre los metaplasmos y las figuras (schema) como procedimientos admitidos o excusables en el ámbito de las palabras aisladas o conectadas, respectivamente. Dice Nebrija:

Si en alguna palabra no se comete vicio alguno, llama se lexis, que quiere dezir perfecta dición. Si en la palabra se comete vicio que no se pueda sofrir, llama se barbarismo. Si se comete pecado que por alguna razón se puede escusar, llama se metaplasmo. Esso mesmo, si en el aiuntamiento de las partes de la oración no ai vicio alguno, llama se phrasis, que quiere dezir perfecta habla. Si se comete vicio intolerable, llama se solecismo. Si ai vicio que por alguna razón se puede escusar, llama se schema. Assí que entre barbarismo y lexis está metaplasmo; entre solecismo y phrasis está schema ${ }^{11}$.

Precisamente son estos "vicios" o "pecados excusables" de los que habla Nebrija lo que nos interesa, sobre todo si tenemos en cuenta que muchos de los ejemplos con que ilustra su teoría son versos, un gran número de Juan de Mena.

También José Antonio Mayoral, que combina la sistematización de Lausberg con la de Nebrija y Correas, ejemplifica todos estos recursos con poetas, en este caso de los Siglos de Oro, y

${ }^{11}$ Nebrija, Antonio de: Gramática de la lengua castellana. Estudio y edición de Antonio Quilis. Madrid: Editora Nacional, 1984 (2ª ed.), p. 211. 
relaciona con los metaplasmos por supresión, como ya lo hiciera la tradición clásica (Lausberg, y el citado Nebrija en la tradición española), fenómenos métricos tan habituales como la sinéresis (poe-ma por po-e-ma) y la sinalefa (ver-dey rosa por ver-de-yro-sa) o la denominada ecthlipsis, especie de sinalefa consonántica: (sutilladrón) ${ }^{12}$. Y otro tanto sucede con la diéresis y el hiato, que corresponderían a los metaplasmos por adición: la diéresis, separación silábica de un diptongo ( $r u$-i-do por rui-do), y el hiato o dialefa, como fenómeno que contraviene la tendencia a la sinalefa en la pronunciación habitual y en la métrica.

En este grupo de fenómenos métrico-retóricos encontramos otros recursos determinados por cambios producidos en la cantidad silábica o en la posición acentual, como las llamadas diástole y sístole. La diástole (o éctasis), que consiste en el alargamiento de una vocal, se sumaría a la lista de metaplasmos por adición, mientras que la sístole, procedimiento de abreviación de una vocal larga, formaría parte de los metaplasmos por supresión. Al carecer el castellano de cantidad vocálica asimila tales procedimientos a la posición acentual, de tal forma que en la diástole se produciría un desplazamiento del acento de una sílaba a la siguiente (adecúa por adecua), y en la sístole se convertiría en tónica la sílaba anterior (cénit por cenit), cambios acentuales rechazados por la norma culta.

La cuestión nos plantea, como sintetiza José Perona, "si estamos en presencia de un error o en presencia de un resplandor, de un vulgarismo o de una licencia poética"13. El espacio literario puede convertir en "licencia" o "figura" este tipo de fenómenos por el solo hecho de utilizarlos. Un caso particular lo tenemos en aquellos textos que los incorporan como reflejo del habla vulgar de determinados individuos o en la caracterización idiomática, cultural o social, de la persona que toma la palabra. Pero lo habitual, tal y como lo corroboran los numerosos ejemplos que pueblan los manuales, es que sean aplicados en el terreno poético al

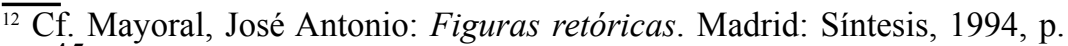
45.

${ }^{13}$ Perona, J.: "Cambios fonéticos esporádicos: metaplasmos, vulgarismos o licencias fonológicas", en Estudios de Lingüística. Universidad de Alicante, 2002, 16, pp. 5-36, p. 30. Disponible en http://rua.ua.es/dspace/ bitstream/10045/6213/1/EL_16_14.pdf.
} 
cómputo silábico o al análisis acentual, según los casos.

De este modo la retórica sistematiza unas posibilidades de realización lingüística que serán validadas por la realidad pragmática en la que se inscriban, ofreciendo así una teoría maleable, con distintos ámbitos de aplicación. Es evidente que la poesía contemporánea, ampliamente liberada de la medida silábica, presenta un limitado empleo de estas licencias, que contrasta con la relevancia que tuvieron en otras épocas literarias y en otros momentos de la historia de nuestra lengua.

\section{III}

Las figuras de repetición, otro subtipo de las figuras de dicción, se basan en el empleo de un elemento verbal que ha aparecido previamente. La repetición es, pues, la clave de la caracterización de este tipo de recursos, igual que, como han destacado tantos autores, sucede con el verso, precisamente porque es clave en la naturaleza del ritmo. Es el caso de quienes han visto en la repetición el rasgo que diferencia el verso de la prosa ${ }^{14}$, o de quienes han destacado los mecanismos de repetición como el soporte diferenciador del verso libre ${ }^{15}$.

La perspectiva amplia con la que la retórica clásica enfoca la repetición elocutiva (ámbito fónico, léxico-semántico y sintáctico), posibilita una utilización y ejemplificación tanto en contextos oratorios como poéticos. Sin embargo, desde muy pronto el hecho de que estas figuras tomaran como marco los límites concretos de un período, frase o secuencia lingüística (en prosa) favoreció su rápida asimilación al marco del verso, de tal forma que ambos segmentos, delimitados por pausas, vienen a equipararse. Es habitual que los manuales de retórica caractericen la

\footnotetext{
${ }^{14}$ Véase, por ejemplo, Lotman, I.: La estructura del texto artístico. Madrid: Itsmo, 1988 [1973].

15 Así lo señala, siguiendo la estela de Jakobson, Lázaro Carreter, F: "Función poética y verso libre", en Estudios de poética. Madrid: Taurus, 1972, pp. 51-62. Sobre la tipología del verso libre atendiendo a la repetición de elementos fónicos o de pensamiento, Vid. PARAÍSO, Isabel: El verso libre hispánico. Orígenes y corrientes. Madrid: Gredos, 1985, y desde un planteamiento histórico y teórico, el trabajo más reciente de Utrera Torremocha, M. ${ }^{a}$ V.: Historia y teoría del verso libre. Sevi1la: Padilla Libros, 2001.
} 
anáfora o la epífora, por poner un ejemplo, desde la perspectiva del verso, y de la frase, si el texto está en prosa, de tal forma que ambas modalidades participan de una misma esencialidad rítmica.

Baste para nuestro propósito enumerar algunas de las figuras de repetición más habituales ${ }^{16}$. En el nivel fonológico, la aliteración, la onomatopeya, el parómeon, el homotéleuton y el homeóptoton, se definen por la recurrencia de sonidos en distintas posiciones y sentidos. La rima será la repetición fónica característica del verso.

En el plano léxico-semántico hay una amplia gama de posibilidades que dan nombre a recurrencias enmarcadas en el verso o en la frase: la anáfora $\left(\mathrm{x}_{\ldots} / \mathrm{x}_{\ldots}\right)$, la epífora $\left(\mathrm{x}_{\mathrm{x}} / \mathrm{x}\right)$, la complexio $\left(\mathrm{x} \_\mathrm{y} / \mathrm{x} \_\mathrm{y}\right)$, la geminación $\left(\mathrm{x}, \mathrm{x} \_\right.$), la anadiplosis $(\mathrm{x} / \mathrm{x})$, la epanadiplosis $(\mathrm{x} \quad \mathrm{x})$, el polisindeton, la annominatio (paronomasia, derivatio, figura etimológica, políptoton, traductio), el equívoco o antanaclasis... son algunas de ellas.

En algunos de estos procedimientos estará la raíz de distintas caracterizaciones métricas. La anadiplosis, por ejemplo, que repite la última parte de una secuencia al principio de la que le sigue, es la base de los versos encadenados, con rima entre el final de un verso y la primera parte del verso siguiente. En el siglo XVII Caramuel describe esta posibilidad en distintas composiciones métricas. Dice en su Primus Calamus al hablar del soneto concatenado:

La concatenación pide que la primera parte del verso siguiente consuene con la última del precedente. Es una Figura Rítmica que no sólo puede encontrarse en los Sonetos, sino también en otras Composiciones. Pues, si compones Sonetos Concatenados, ¿por qué no vas a poder también componer Trísticos, Tetrásticos o Pentásticos (en español, Tercetos, Cuartillas o Quintillas)? ${ }^{17}$

${ }^{16}$ Remitimos sobre estos aspectos al completo y documentado estudio de Frédéric, M.: La répétition. Etude linguistique et rhétorique. Tübingen: Max Niemeyer Verlag, 1985, que aborda la repetición desde un punto de vista retórico y lingüistico y tiene en cuenta no sólo los hechos de elocución del lenguaje elaborado, sino también los de la elocución espontánea.

${ }^{17}$ Caramuel, J.: Primus Calamus ob oculus exhibens Rhithmicam. Primer Cálamo de Juan Caramuel. Tomo II, Rítmica. Introducción y edición al cuidado de Isabel Paraíso. Valladolid: Universidad de Valladolid, 2007, 
Y algo similiar sucede con el llamado soneto con repetición. Aunque el mismo autor admite que la repetición podrá asimilarse a la concatenación, el hecho de que sea más frecuente le hace considerarla aparte. También posible en cualquier ritmo y en cualquier metro, no sólo en el soneto, consistirá en que la última palabra de un verso se repita en el inicio del verso siguiente.

Otros fenómenos métricos basados en la repetición, como el del eco, darán nombre también a similares construcciones que subrayan aspectos lúdicos e ingeniosos ${ }^{18}$.

Los recursos que se basan en la repetición de elementos sintácticos tienen gran interés en las relaciones entre retórica y métrica. La superación de los esquemas fónicos encuentra en los movimientos de repetición de palabras y estructuras una dimensión más definida y amplia de la significación rítmica. Recordemos la distinción entre el ritmo como fenómeno del habla inseparable de la frase y el metro como hecho de norma abstracto en Octavio Paz, para quien "el ritmo es inseparable de la frase; no está hecho de palabras sueltas, ni sólo medida o cantidad silábica, acentos y pausas: es imagen y sentido" 19 .

Por otro lado, el llamado "ritmo de pensamiento", definido por sus componentes lingüísticos, se ha señalado como característico de la prosa, frente al ritmo del verso, de tipo acentual y cuantitativo $^{20}$. Su base es el paralelismo con sus múltiples realizaciones (isocolon, parison, correlación...). Recordemos que el isocolon, caracterizado por la igualdad o semejanza en el núme-

pp. 361-362.

18 Vid. Domínguez Caparrós, J.: Diccionario de métrica española. Madrid: Alianza Editorial, 1999, pp. 125-127.

${ }^{19}$ Y sigue diciendo: "Ritmo, imagen y sentido se dan simultáneamente en una unidad indivisible y compacta: la frase poética, el verso". PAZ, O.:

El arco y la lira. México: F.C.E., 1986, cit. en Domínguez Caparrós, J.: Métrica española, cit., p. 37.

${ }^{20}$ Cf. Paraíso, I.: Teoría del ritmo de la prosa. Barcelona: Planeta, 1976, p. 48 y ss. Dice sobre el ritmo de pensamiento: "Según sus modalidades, se lo conoce bajo diferentes nombres: "estribillo", "verso anafórico", (repeticiones de frase), "palabras clave", "símbolos", "figuras de estilo basadas en la repetición de palabras" -epanáfora, epanalepsis, epífora, anadiplosis, epanadiplosis, etc.- (repeticiones de una o varias palabras), "paralelismo", "correlación", "quiasmo" (repeticiones de esquemas sintácticos), etc. En la prosa muchas de estas modalidades reaparecen, y lo hacen sobre todo en la prosa oratoria y la lírica". Ibid., p. 52. 
ro de sílabas de varias secuencias, viene a ser una especie de verso en prosa, o más concretamente, un correlato del isosilabismo en poesía, mientras que el parison implica igualdad estructural o sintáctica entre frases y oraciones; la correlación conlleva una semejanza estructural por la disposición simétrica de las palabras en las oraciones, y no por la coincidencia en la sintaxis. El siguiente ejemplo de parison de Fr. Antonio de Guevara que ponen Azaustre y Casas en su Manual de retórica es suficientemente ilustrativo:

El dios Cupido y la diosa Venus no quieren en su casa sino a mancebos que los puedan servir y a liberales que sepan gastar, y a libres que puedan gozar, y a pacientes que puedan sufrir, y a discretos que sepan hablar, y a secretos que sepan callar, y a fieles que sepan agradescer, y animosos que sepan perseverar. (Epístolas familiares) ${ }^{21}$

En este nivel sintáctico no es necesario insistir ahora en el valor de las recurrencias y los paralelismos fónicos, gramaticales y semánticos en la unidad rítmica del poema, en su literalidad y estructuración interna, en la esencia misma de la secuencia poética como factor constructivo del verso, tal y como señalaron los formalistas, o en modelos explicativos de la construcción recurrente del texto poético como los de los couplings o emparejamientos de S. R. Levin ${ }^{22}$. Se trata de procedimientos de indudable repercusión semántica y estructural que resaltan la realidad unitaria de la composición poética, de manera especial del verso libre, y como veremos después, de los textos oratorios $\mathrm{y}$ artísticos en general.

Sinónimos, tautologías, pleonasmos, reiteraciones, redundancias, isotopías..., constituyen dentro del campo semántico el otro gran bloque de repeticiones. En este sentido no hay que olvidar que la repetición de un elemento lingüístico es siempre una llamada de atención que responde a un deseo de aislar, de destacar y grabar en el receptor una sensación, una impresión,

\footnotetext{
${ }^{21}$ Azaustre, Antonio y Casas, Juan: Manual de retórica española. Barcelona: Ariel, 1997, p. 103.

${ }^{22}$ Cf. Levin, S. R.: Estructuras lingüisticas en la poesía. Madrid: Cátedra, 1974.
} 
una imagen, una determinada referencialidad. Y esto refuerza la expresividad del texto y la coherencia y cohesión textuales.

El salto de la frase al texto lo explica magníficamente Mayoral cuando habla, siguiendo a Plett, de equivalencias textuales y figuras de repetición en el nivel textual. Aquí se incluirían los estribillos, que condensan con frecuencia la idea principal y desempeñan un importante papel en el desarrollo de un texto, y construcciones similares, como la repetición de bloques estróficos o grupos de versos, que, aunque posibles también en prosa, son de marcada relevancia en poesía ${ }^{23}$.

El distinto grado de vinculación de estas equivalencias textuales con las formas estrófico-poemáticas será el criterio seguido para su clasificación. Recordemos, por ejemplo, la importante función que realizan los estribillos en villancicos, letrillas, romances y glosas, en los esquemas estróficos más claros, o el de repeticiones de carácter libre no condicionadas por la estrofa, como anáforas, epíforas, complexiones, etc. de carácter textual. Así ocurre en la canción, muy difundida en los Siglos de Oro, que nos trae a la memoria el conocido verso garcilasiano "Salid sin duelo, lágrimas corriendo".

Atención aparte merecería el encabalgamiento, fenómeno típicamente versal de trascendencia estilística, que refleja la tensión entre la sintaxis lógica y rítmica, del que se han ocupado numerosos estudios.

\section{IV}

Junto a los tropos y figuras, la composición (compositio) es la otra gran parte de la elocutio retórica. Próxima a las mencionadas figuras de repetición, se centra en el análisis de la combinación armónica de los elementos elocutivos, en su ordenación desde el punto de vista fonético y sintáctico, por lo que presta una atención especial al ritmo. Dionisio de Halicarnaso estableció en el siglo I a.C. que su función es "disponer de manera debida y congruente entre sí las palabras, conferir a los miembros

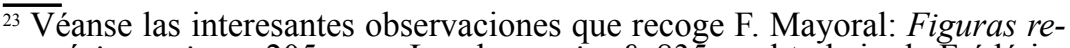
tóricas, cit., p. 205 y ss., Lausberg, cit., \& 835, y el trabajo de Frédéric: La répétition, cit., p. 68. 
el ajuste conveniente y distribuir adecuadamente el discurso en períodos" ${ }^{24}$.

Sin ánimo de extendernos en la compleja sistematización clásica, no podemos dejar de mencionar su importancia como punto de conexión o comparación entre los procedimientos rítmicos de la prosa y los del verso. Aunque ya Aristóteles proscribiera el verso en la prosa, en su Retórica defendió con claridad el ritmo, como hiciera también en su Poética al considerarlo una de las dos causas de la poesía, junto a la mímesis. Dionisio de Halicarnaso desarrolla esta idea y defiende que "es con mucho en la composición donde antes que en ningún otro lugar residen el placer y el poder persuasivo de la palabra" 25 . Su intención es demostrar la importancia de la compositio tanto en textos poéticos como oratorios, ya que, aunque se mantenga fija la selección de palabras de un poema, con que se varíe la composición se produce un nuevo modelo métrico y una alteración de la forma, del estilo, del carácter y de la significación del poema ${ }^{26}$. Y lo mismo sucede en la prosa.

También Cicerón, uno de los teóricos más atentos al ritmo de la prosa, argumentará la conveniencia de la compositio en la prosa, no sólo para hablar de forma elegante y agradar (igual que los poetas eran escuchados con placer), o evitar el hastío del auditorio por medio de la variedad, sino también por la fuerza persuasiva del ritmo. Un discurso, si está elaborado de forma $n a-$ tural, si revela una cuidada y no artificiosa elección y colocación de los sonidos, de las palabras y de las frases en sus distintas partes, tiene mucha más fuerza que si está suelto. Comparándolo con un atleta o un gladiador, el orador-dice Cicerón- no da un golpe duro si su ataque no es armonioso ni esquiva bien el ataque del contrario:

Tal me parece a mí el estilo de estos que no acaban rítmicamente sus frases y tan lejos está la frase de perder nervio por colocar bien las palabras -cosa que suelen decir aquellos que por falta de maestros, por torpe-

\footnotetext{
${ }^{24}$ Halicarnaso, D.: "La composición literaria", en Tres ensayos de crítica literaria, Madrid: Alianza Editorial, 1992, pp. 122-123.

${ }^{25}$ Ibid., p. 123.

${ }^{26}$ Cf. ibid. p. 129.
} 
za de ingenio o por pereza de espíritu no consiguen eso- que de otra forma no puede haber en ella ímpetu ni fuerza. ${ }^{27}$

Razones de peso todas ellas de las que había sido consciente Isócrates cuando introdujo el ritmo en la prosa ${ }^{28}$. La combinación o mezcla de intervalos largos y breves justifica la movilidad o estatismo del discurso. Los procedimientos son los mismos que los de la poesía, pero a diferencia de ésta, deben utilizarse de manera natural. Muchas veces se hacen versos en la prosa sin darnos cuenta, pero la prosa -considerada por Cicerón más difícil que la poesía- debe mostrar un equilibrio rítmico, una mezcla moderada de ritmos, de forma que ni sea esclava del mismo ni lo utilice libremente ${ }^{29}$.

El orador ideal que describe Cicerón debe procurar enlazar bien las palabras al principio y al final, que tengan los sonidos más armoniosos posibles, que los períodos se presenten redondeados y que suenen de forma rítmica y adecuada ${ }^{30}$. En la manifestación oral de un texto que tiene por objeto influir en el auditorio con una determinada intención, el aspecto auditivo es más importante de lo que pueda parecer. Por eso Cicerón valora las cualidades rítmicas de los sonidos y de sus combinaciones, para que no se produzcan hiatos ni asperezas ${ }^{31}$, así como palabras tomadas del acervo común que suenen bien, "no palabras

${ }^{27}$ Cicerón, El Orador. Madrid: Alianza Editorial, 2006, párrs. 228-229.

${ }^{28}$ Dice Cicerón: "Y es que el oído, o la mente, advertida por el oído, contiene en sí misma una especie de medida natural de todos los sonidos. Por ello, ve lo que es demasiado largo y lo que es demasiado corto y siempre espera algo acabado y medido; percibe que ciertas frases están mutiladas y casi cortadas y le chocan, como si se le quitara lo que se le debe; que otras son demasiado largas y como corriendo de una forma exagerada, cosa que el oído rechaza aún más, ya que en la mayoría de los casos, pero sobre todo en esta materia, lo mucho molesta más que lo poco. Así pues, de la misma forma que la poética y el verso han sido inventados gracias a la limitación impuesta por los oídos y a la observación de los técnicos, así también en la prosa se ha advertido -más tarde sin duda, pero según la indicación de la misma naturaleza- que la secuencia de las palabras y el final de las frases obedecen a ciertas leyes". Ibid., párrs. 177-178.

${ }^{29}$ Cf. ibid., párr. 198.

${ }^{30} \mathrm{Cf}$. ibid., párr. 149.

${ }^{31}$ Dice al respecto: "Y es que, por muy agradables y profundos que sean los pensamientos, si se exponen con palabras mal colocadas, ofenderán a los oídos, cuyo juicio es muy exigente". Ibid., párr. 150. 
rebuscadas, como hacen los poetas" 32 .

En cuanto a la colocación de las palabras, el orador ha de buscar cierto redondeamiento en la expresión a través básicamente de la simetría. Ésta se convierte en una fuente rítmica natural. Enlazando con el apartado anterior, Gorgias, al que pone como ejemplo Cicerón, fue el referente indiscutible de la simetría en la composición. El empleo de palabras que tengan iguales terminaciones casuales, la colocación de elementos simétricos, o la colocación de contrarios en oposición, son algunos de los procedimientos que conectan con los recursos antes mencionados, que proporcionan musicalidad por su propia naturaleza ${ }^{33}$. Sirva como ejemplo el siguiente fragmento en prosa oratoria que pone Cicerón:

Existe, en efecto, jueces, una ley, no escrita, sino innata, ley que no hemos aprendido, recibido, leído, sino que de la misma naturaleza la hemos recibido, bebido, extraído, y para la cual no hemos sido enseñados, sino formados, no instruidos, sino imbuidos. ${ }^{34}$

El último punto es el del periodo, de los incisos y los miembros. Aquí la noción de numerus es fundamental, como equivalente del metro poético en la prosa, o la misma distinción clásica entre estilo suelto (de ritmo relajado tendente a la coordinación, sin las ataduras del numerus, y basado en la regularidad de la ordenación sintáctica) y el estilo periódico (determinado por el numerus, desarrolla el contenido argumentativo a través de una serie de períodos o partes interrelacionadas, preferentemente a través de la subordinación). Con respecto al numerus la preceptiva retórica reivindicó con insistencia la variedad y la evitación del metro poético en prosa (principio antimétrico) para no restarle verosimilitud al discurso ${ }^{35}$.

\footnotetext{
32 Párr. 163.

${ }^{33}$ Cf. párrs. 164 y 165.

${ }^{34}$ Párr. 165.

${ }^{35}$ Para un repaso más detallado de la teoría del numerus aplicado a la prosa de Fray Luis de León, vid. Márquez, M. A.: "El numerus en la prosa de Fray Luis de León", en M. V. Utrera Torremocha y M. Romero Luque (eds.), Estudios literarios in honorem Esteban Torre. Sevilla: Universidad de Sevilla, 2007, pp. 241-253.
} 
Como vemos, la atención retórica a la estructuración oracional en la compositio no sólo es efectiva en el análisis estilístico de la prosa literaria, sino que puede ser también eficaz en el verso. Pensemos, por ejemplo, en sonetos tan estudiados como el clásico de Garcilaso "En tanto que de rosa y azucena" o el de Góngora "Mientras por competir con tu cabello", en los que la simetría oracional se une a la versal para reforzar un conjunto armónico y acabado, de ritmo total. La relación de estas estructuras compositivas con figuras de repetición como las anteriormente señaladas: paralelismos, anáforas, polisíndeton, etc., refuerza claramente su expresividad y se erige en elemento significativo de primer orden.

Otro tanto se puede decir del poema en prosa, de creciente interés en la poesía del siglo pasado, en el que no nos vamos a detener ahora ${ }^{36}$.

\section{V}

Desde la perspectiva amplia de la ordenación discursiva, la dispositio ofrece un campo no desdeñable de estudio y aproximación a la versificación. El verso es el marco en el que se ubican las palabras que selecciona y ordena el poeta en un proceso deslindable sólo metodológicamente del resto de las operaciones nucleares.

La misma retórica que reglamenta la ubicación-ordenaciónestructuración en los argumentos, de las partes de la oración, de los párrafos y de las palabras en la frase (compositio) también ofrece una zona de reflexión sobre la ordenación versal.

La consideración, por ejemplo, de la posición que ocupa una unidad lingüística, o su repetición al principio, en medio o al final de un verso, estrofa o poema, conlleva una determinada intencionalidad estética y está al servicio de la consecución de un sentido. Cuando Lotman se pregunta por el papel estructural

\footnotetext{
${ }^{36}$ Sobre los avatares históricos que experimenta la prosa en su consideración artística y la relación entre prosa, poesía y verso, con atención particular al poema en prosa, vid, el trabajo de Utrera Torremocha, M. ${ }^{\mathrm{a}}$ Victoria; Teoría del poema en prosa. Sevilla: Universidad de Sevilla, 1999, p. 24 y ss. Véase también Márquez Guerrero, M. A.: "El poema en prosa y el principio antimétrico". Epos. Revista de Filología, 2003, 19, pp. 133-150.
} 
de las repeticiones métricas y por la función que desempeñan en la construcción general del texto ${ }^{37}$, lo que está haciendo es plantearse el poder significativo de las estructuras métricas, la inseparabilidad de sonido y sentido, el significado artístico del ritmo ${ }^{38}$.

En la apelación directa al receptor que supone todo texto poético, literario o retórico, la ubicación de las formas lingüísticas constituye un refuerzo añadido que se suma al espacio ocupado por reiteraciones y recursos elocutivos basados en la repetición, bien de fonemas (aliteraciones, isotopías fónicas, rimas...), bien de otros procedimientos como los arriba estudiados.

Más allá de la orientación estrictamente formal del estudio del verso, la estrofa, y el poema en su conjunto, sobre todo cuando se trata de una suma integradora de estrofas, la dispositio retórica puede iluminar o justificar la ordenación interna de los componentes estróficos dentro del poema. La rentabilidad textual de las partes de la dispositio clásica (las generales exordio, narratio, argumentatio y peroratio), permite su aplicación al análisis específico de textos poéticos, de su producción y recepción, en el marco general de la reivindicada Retórica General Textual ${ }^{39}$.

Sobre este tema se ha señalado la correspondencia entre el verso y la frase, por un lado, y la estrofa, en tanto conjunto de versos, con lo que pudiéramos asimilar a una cláusula sintácticodispositiva. En ese sentido han sido analizadas, por ejemplo, las variaciones estructurales del soneto renacentista con respecto al soneto barroco atendiendo a la distribución y función de sus componentes: abundancia de la isodistribución dual en el Renacimiento, más natural, frente a isodistribución múltiple barroca, que produce una impresión de mayor artificio ${ }^{40}$.

\footnotetext{
$\overline{{ }^{37} \mathrm{Cf}}$. Lotman, I.: Estructura del texto artístico, cit.

${ }^{38}$ Disponemos de una aproximación al tema en el artículo de Domínguez Caparrós, José: "Estructuras métricas y sentido artístico". Entretextos. Revista Electrónica Semestral de Estudios Semióticos de la Cultura, 2004, 3. http://www.ugr. es/ mcaceres/Entretextos/entre3/dominguez.htm.

39 Vid. la síntesis que ofrece Pozuelo, J. M. a: Teoría del lenguaje literario. Madrid: Cátedra, 1988, especialmente en el cap. VIII, "La Neorretórica y los recursos del lenguaje literario", p. 159 y ss.

${ }^{40}$ Cf. García Berrio, A. y Hernández Fernández, M. ${ }^{a}$ T.: Crítica literaria. Iniciación al estudio de la literatura. Madrid: Cátedra, 2006 [2004], p. 97 y ss.
} 
La rentabilidad estructural del soneto es una muestra de algunas posibilidades de enfoque muy iluminadoras en el análisis de otras series o composiciones estróficas que, como toda realización textual, refleja una realidad pragmática específica y una determinada intención comunicativa.

\section{VI}

Plantearnos la relación entre métrica e inventio puede sorprender por tratarse de dos aspectos aparentemente alejados: la métrica parece privilegiar el análisis formal, y la invención se concentra en la búsqueda de los argumentos, de los temas que se van desarrollar. Se trata en este último caso de una fase de indagación, de búsqueda, de rastreo, de elección y necesaria selección de entre innumerables posibilidades temáticas.

La preocupación clásica por la conveniencia y el decoro destacó en el ámbito de la poética la adecuada vinculación entre determinados metros y géneros literarios. Desde la retórica se hizo algo similar cuando se insistió en la correspondencia del estilo rítmico, por ejemplo, con determinados géneros o partes del discurso.

Así, se estableció que el empleo ocasional de un estilo armonioso, con frases delimitadas y redondeadas, simétricas y acabadas, particularmente rentable en el género epidíctico, debía ser utilizado con prudencia en el género forense y deliberativo. Con ello se pretendía evitar el cansancio del auditorio y una sensación de artificiosidad que podía restar credibilidad al discurso y quitarle patetismo. Sólo se recomienda este estilo en los elogios, en las amplificaciones y en las peroraciones, cuando el auditorio, ya conquistado y dominado, se entrega y embelesa ante la fuerza de la palabra ${ }^{41}$. Por otra parte, el orador debía adecuar la composición a los contenidos que quería expresar y utilizar un ritmo rápido para los pasajes tensos, por ejemplo, y un ritmo lento para la exposición de los hechos ${ }^{42}$, o componer un discurso con muchos incisos y miembros en los pasajes en los que se

$\overline{{ }^{41} \mathrm{Cf}}$. Cicerón, El Orador, cit., párr. 210.

${ }^{42}$ Cf. ibid., párr. 212. 
acusaba o se refutaba algún argumento ${ }^{43}$, procurando en todo momento la variedad.

No voy a entrar en la problemática distanciadora a la par que justificadora de forma y contenido, res y verba, idea y expresión, estrofa y motivo poético, en la que podríamos pensar a la hora de explicar determinadas elecciones métricas por parte del poeta. Pero sí plantear interrogantes como qué es lo que justifica la elección de una estrofa o de un esquema métrico determinado, qué conexiones se pueden trazar entre ambos, qué las explicaría, qué temática se ha relacionado más con el uso de determinados versos, estrofas u otros procedimientos métricos, o de qué manera influye la tradición poética y sus modelos en la formación de los cánones métricos.

Lope de Vega, en su canónico Arte nuevo de hacer comedias, asociaba algunos tipos estróficos a temas concretos. Recordemos:

Acomode los versos con prudencia a los sujetos de que va tratando.

Las décimas son buenas para quejas;

el soneto está bien en los que aguardan;

las relaciones piden los romances, aunque en octavas lucen por extremo; son los tercetos para cosas graves, y para las de amor, las redondillas. ${ }^{44}$

Es evidente que los tópicos, tanto los retóricos o lugares comunes como los literarios o tradicionales, pueden desempeñar también una función estructural de guía composicional. M. ${ }^{\mathrm{a}}$ Isabel López Martínez nos recuerda, por ejemplo, el papel estructural que puede tener el tópico literario del viaje en la novela, y que en canciones, cuentos y refranes abundan fórmulas de arranque y de cierre, "casillas que son susceptibles de rellenarse con contenidos distintos" 45 .

$\overline{{ }^{43} \mathrm{Cf}}$. ibid., párr. 225.

${ }^{44}$ Vega, Lope de: Arte nuevo de hacer comedias en este tiempo. Madrid: Cátedra, 2006, p. 148.

${ }^{45}$ Cf. Lopez Martínez, M. ${ }^{\text {a }}$ I.: El tópico literario. Teoría y crítica. Madrid: Arco Libros, 2007, pp. 44-45. Para un enfoque más general desde la literatura comparada, Vid. Naupert, C. (comp.): Tematología y comparatismo literario. Madrid: Arco 
También en composiciones sólidamente secuenciadas, como los cuentos maravillosos o los cuentos tradicionales infantiles, encontramos fórmulas para comenzar y acabar que sitúan al receptor en un escenario referencial que tiende a la repetición y, relacionado con la memoria, a su fijación. Así ocurre con los comienzos de tantos cuentos: "Érase una vez...", "Había una vez...", "Hace mucho tiempo", "Vivía una vez...", "Allá por el año...", "En tiempos de Mari Castaña...", "En un país lejano...”, "Érase que se era..."; y con las fórmulas para acabar tan próximas al verso: “... y fueron felices / y comieron perdices", “... colorín colorado / este cuento se ha acabado", "...esto es verdad y no miento / y como me lo contaron lo cuento", etc. ${ }^{46}$.

El encanto de los llamados cuentos de fórmula consiste en la repetición exacta de una serie de palabras, en acciones que se reiteran, en personajes que siguen patrones similares. Tal necesidad de reiteración, confirmada por el deseo de oír una y otra vez el mismo relato, está en la base del aprendizaje del niño y en los mecanismos psicológicos de conquista y consolidación de la realidad circundante ${ }^{47}$.

Temática y verso, tematología y métrica, tono y género métrico tienden lazos de unión que llevan a pensar, por ejemplo, en las formas y procedimientos métricos más rentables para la expresión de la sátira ${ }^{48}$, el poema humorístico o burlesco, la poesía grave a la que se refería Lope... Igual que el orador busca en las distintas fases de elaboración de su discurso los mejores argumentos, la disposición más adecuada y la expresión más convincente, el poeta, que sigue estas mismas etapas en su proceso creador, selecciona el metro más apropiado al tema, a la intencionalidad que persigue, a las sensaciones que pretende sugerir o al efecto que busca provocar.

Libros, 2003.

${ }^{46}$ Cf. Pelegrín, A.: La aventura de oír. Cuentos tradicionales y literatura infantil. Madrid: Anaya, 2004, pp. 133-134.

${ }^{47}$ Cf. ibid., p. 84 y ss.

${ }^{48}$ Vid. Dominguez Caparrós, J.: "Métrica y sátira". Rhythmica. Revista española de metrica comparada, 2008, V-VI, 5-6, pp. 7-21. 


\section{VII}

En este apretado recorrido por las partes tradicionales de la retórica llegamos a la memoria y a la acción. Con la literaturización de la retórica memoria y actio fueron relegadas a un segundo plano, hasta el punto de desaparecer de nuevo del núcleo retórico básico y experimentar una significativa transformación, sobre todo con la gran crisis de la retórica en el siglo $\mathrm{XIX}^{49}$.

La memoria clásica, sólidamente sistematizada en la Rhetorica ad Herennium, resaltó el poder evocador de las imágenes en la fijación de los recuerdos, de las palabras y de las ideas. Una cultura predominantemente oral como la de la antigua Grecia se preocupó pronto por fijar las grandes piezas oratorias para estudiarlas e imitarlas y proporcionar la técnica para retener y ejecutar los discursos. De este modo incorporó a las partes nucleares de inventio, dispositio y elocutio estas otras dos técnicas: memoria y actio.

En cuanto a la poesía, la propia naturaleza del verso favorece su memorización: la rima, las repeticiones de toda índole, las simetrías, el ritmo, en definitiva, son elementos que potencian la perdurabilidad mental del texto. De esta forma se conjugan las valencias temporales del ritmo con las espaciales de las imágenes memorísticas ${ }^{50}$.

Desde la oratoria el interés pragmático por la fijación de determinados contenidos o expresiones en el receptor procede de la orientación didáctica de la retórica clásica. La memoria, fundamentalmente orientada al proceso de creación y ejecución del discurso, interesa también desde la perspectiva del receptor. El texto se configura, se organiza y se expresa pensando también en que el auditorio retenga lo que queremos que retenga. No en vano el ornatus se justifica como llamada de atención al auditorio para evitar el taedium.

Así lo apreciamos en Luis Vives cuando aconseja determinados procedimientos para conseguir que un oyente que no retiene

\footnotetext{
$\overline{{ }^{49} \mathrm{Vi}}$. un análisis más detallado en nuestro libro De la Retórica a la Teoría de la literatura, cit., p. 117 y ss.

${ }^{50}$ Para un repaso sobre la evolución del arte de la memoria desde la antigüedad clásica al siglo XVII, remitimos al estudio ya clásico de Yates, F.: El arte de la memoria. Madrid: Taurus, 1974 [1966].
} 
las cosas con facilidad memorice lo que se le dice. En su opinión son más provechosas las sentencias breves, adornadas con figuras y armoniosas en el ritmo, las palabras muy usadas, el orden natural, el que los ejemplos sean pocos y repetidos y el destacar de forma especial aquello que queremos que se fije más. La melodía en las poesías y el ritmo corrigen en gran medida esta falta de atención y de retentiva, dice Vives ${ }^{51}$.

Tradicionalmente se han estimado las ventajas del verso en la memorización de contenidos y preceptos. La propia teoría literaria asumió desde muy pronto esta y otras formas para amenizar su aprendizaje ${ }^{52}$. Así, desde la Epístola a los Pisones de Horacio, fueron muchas las preceptivas escritas en verso, como las de Boileau, Artiga, Pérez de Camino o Martínez de la Rosa, por citar algunas de las más conocidas.

En este sentido, Vives, que había excluido la memoria de la retórica, fue muy claro cuando escribió sobre la utilidad del verso para la memoria:

El verso ayuda mucho a la memoria con la armonía y medida del ritmo $\mathrm{y}$, así, aquellas materias que sean dignas de recordar, deben adaptarse a ritmos. Las sentencias que se entremezclan en el poema como piedras preciosas, si no de forma más sublime e ilustre, quisiera yo sujetarlas de forma más rítmica y más rotunda, lanzándolas como un dardo para que se adhieran más firmemente y esto ha de hacerse no sólo en todo el poema, sino especialmente en la elocución escénica. Así, el espectador las llevará fácilmente a casa, las recordará y las repasará para sí. ${ }^{53}$

Aunque los avances tecnológicos y el peso de la imagen en la cultura actual han restado atención a la memoria como procedimiento didáctico, no han dejado de destacarse sus ventajas en la educación infantil. Las primeras palabras del niño van asociadas al juego, al ritmo y a la sorpresa, por lo que ocupan un lugar

${ }^{51}$ Cf. Vives, Juan Luis: El arte retórica. De ratione dicendi. Estudio introductorio de Emilio Hidalgo-Serna; edición bilingüe, traducción y notas de Ana Isabel Camacho. Barcelona: Anthropos, 1998, p. 185.

${ }^{52} \mathrm{El}$ interesado por la utilización de determinadas formas pseudo literarias en la configuración formal de textos de teoría literaria en el siglo XVIII puede consultar nuestro artículo "Las formas de la teoría literaria en el siglo XVIII. El Fray Gerundio como retórica novelada", en Revista de literatura, LXI, no 121, 1999, pp. 61-81, especialmente, pp. 61-75.

${ }^{53}$ Vives: El arte retórica, cit., p. 277. 
central múltiples manifestaciones poéticas orales, canciones, retahílas, cuentos, juegos mímicos..., que a todos nos vienen a la memoria, y en las que resulta determinante la voz, el sonido, la entonación, el gesto y la dramatización ${ }^{54}$.

La puesta en escena del discurso clásico ${ }^{55}$ conecta directamente en nuestros días con una amplia gama de profesiones cuyo principal instrumento es el lenguaje y que requieren un buen dominio del arte de la palabra ${ }^{56}$. El discurso político, el judicial, el publicitario, el del docente o el científico... comparten con la lectura escenificada de cuentos, el recitado de poemas o las representaciones teatrales, una atención diferenciada hacia la pronunciación y el gesto.

Como en el caso anterior, esta práctica se presenta en la actualidad en contextos puntuales, en los que prima la naturalidad en la acción y en la pronunciación. La distinción metodológica que hiciera Jakobson entre modelo y ejemplo de verso y modelo y ejemplo de ejecución, tiene en esta última dualidad uno de sus sentidos más interesantes por su aplicabilidad a otros ámbitos ${ }^{57}$.

En este rápido recorrido por la retórica, que en ningún momento ha pretendido ser exhaustivo ni definitivo, hemos visto cómo la retórica, en tanto teoría explicativa del proceso de elaboración discursiva y literaria en general, muestra, también en el terreno de la métrica, su permeabilidad y su vigencia. Desde una perspectiva amplia y actual pone también al servicio del verso sus instrumentos de análisis, de tal forma que complementa aquellos que apenas si quedaron esbozados en la retórica clásica, y refuerza aquellos otros que desde sus mismos orígenes acercaron las distancias que median entre el verso y la prosa.

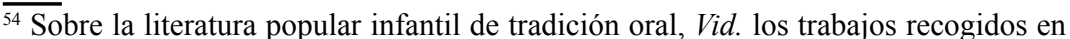
Cerrillo, Pedro C. y Sánchez Ortiz, César: La palabra y la memoria (Estudios sobre Literatura Popular Infantil). Cuenca: Ediciones de la Universidad de CastillaLa Mancha, 2008.

${ }^{55}$ Para un recorrido histórico por la actio, Vid. Díez Coronado, M. ${ }^{\mathrm{a}}$ A. Retórica y representación: historia y teoría de la "actio". Logroño: Ed. Instituto de Estudios Riojanos, 2003.

${ }^{56}$ Véase el reciente trabajo de Hernández Guerrero, J. A. y M. ${ }^{a}$ C. García Tejera: El arte de hablar. Manual de retórica práctica y de oratoria moderna. Barcelona: Ariel, 2008 ( $3^{\mathrm{a}}$ ed.) [2004].

${ }^{57}$ Cf. Jakobson, R.: "Lingüística y poética", en Ensayos de lingüística general. Barcelona: Ariel, 1984, pp. 347-395 [1960]. 
Se abre un campo de múltiples y diversos senderos que habrán de completar investigaciones futuras.

\section{Bibliografía}

ARADRA SÁnchez, R. Ma .: De la Retórica a la Teoría de la literatura (siglos XVIII $y$ XIX). Murcia: Servicio de Publicaciones de la Universidad de Murcia, 1997.

-: "Las formas de la teoría literaria en el siglo XviII. El Fray Gerundio como retórica novelada". Revista de literatura, 1999, LXI, 121, pp. 6181.

ARISTÓTELES: Retórica. Introducción, traducción y notas por Quintín Racionero. Madrid: Gredos, 1990.

Aristóteles, Horacio: Artes poéticas. Edición bilingüe de Aníbal González. Madrid: Taurus, 1987.

Azaustre, A.; y CASAS, J.: Manual de retórica. Barcelona: Ariel, 1997.

Bobes, C.; BaAmonde, G., Cueto, M., Frechilla, E. y Marful, I.: Historia de la teoría literaria, II, Transmisores, Edad Media, Poéticas clasicistas. Madrid: Gredos, 1998.

Caramuel, J.: Primus Calamus ob oculus exhibens Rhithmicam. Primer Cálamo de Juan Caramuel. Tomo II, Rítmica. Introducción y edición al cuidado de I. Paraíso. Valladolid: Universidad de Valladolid, 2007.

Cerrillo, P. C.; y Sánchez Ortiz, C.: La palabra y la memoria (Estudios sobre Literatura Popular Infantil). Cuenca: Ediciones de la Universidad de Castilla-La Mancha, 2008.

CICERÓn: El Orador. Madrid: Alianza Editorial, 2006.

Díez Cononado, M. a A.: Retórica y representación: historia y teoría de la “actio”. Logroño: Ed. Instituto de Estudios Riojanos, 2003.

Domínguez CAPARrós, J.: Contribución a la historia de las ideas métricas en los siglos XVIII y XIX. Madrid: C.S.I.C., 1975.

—: "La métrica en los estudios literarios". Epos, 1992, 8, pp. 245-261.

—: Métrica española. Madrid: Síntesis, 1993.

—: Diccionario de métrica española. Madrid: Alianza Editorial, 1999.

—: "Estructuras métricas y sentido artístico". Entretextos. Revista Electrónica Semestral de Estudios Semióticos de la Cultura, 2004. http:// www.ugr.es/ mcaceres/Entretextos/entre3/dominguez.htm.

-: "Métrica y sátira". Rhythmica. Revista española de métrica comparada, 2008, V-VI, 5-6, pp, 7-21.

FRÉDÉRIC, M.: La répétition. Étude linguistique et rhétorique. Tübingen: Max Niemeyer Verlag, 1985

García Berrio, A.; y Hernández Fernández, M. a T.: Crítica literaria. Iniciación al estudio de la literatura. Madrid: Cátedra, 2006 [2004]. 
Halicarnaso, D. de: La composición literaria, en Tres ensayos de crítica literaria, Madrid: Alianza Editorial, 1992.

Hernández Guerrero, J. A.; y García Tejera, M. ${ }^{a}$ C. : El arte de hablar. Manual de retórica práctica y de oratoria moderna. Barcelona: Ariel, 2008 ( $3^{\mathrm{a}}$ ed.) [2004].

JAKOBSON, R.: "Lingüística y poética", en Ensayos de lingüistica general. Barcelona: Ariel, 1984, pp. 347-395 [1960].

Lausberg, H.: Manual de retórica literaria. Fundamentos de una ciencia de la literatura, Madrid: Gredos, 1990, 3 vols. [1966].

Lázaro Carreter, F.: "Función poética y verso libre", en Estudios de poéti$c a$, Madrid: Taurus, 1972, pp. 51-62.

Levin, S. R.: Estructuras lingüisticas en la poesía. Madrid: Cátedra, 1974.

LÓPEZ EIRE, A.: Retórica clásica y teoría literaria moderna. Madrid: Arco Libros, 1997.

Lopez Martínez, M. ${ }^{a}$ I.: El tópico literario. Teoría y crítica. Madrid: Arco Libros, 2007.

Lotman, I.: La estructura del texto artístico. Madrid: Istmo, 1988 [1973].

MÁrquez Guerrero, M. A.: "El poema en prosa y el principio altimétrico". Epos. Revista de Filología, 2003, 19, pp. 133-150.

-: "El numerus en la prosa de Fray Luis de León", en M. ${ }^{a}$ V. UtRERA TORREMOCHA y M. Romero Luque (eds.), Estudios literarios in honorem Esteban Torre. Sevilla: Universidad de Sevilla, 2007, pp. 241-253.

Mayoral, J. A.: Figuras retóricas. Madrid: Síntesis, 1994.

Murphy, J. J.: La retórica en la Edad Media. Historia de la teoría de la retórica desde San Agustín hasta el Renacimiento. México: F.C.C., 1986 [1974].

NauPert, C. (comp.): Tematología y comparatismo literario. Madrid: Arco Libros, 2003.

NebriJA, A. de (1492): Gramática de la lengua castellana. Gramática de la lengua castellana, estudio y edición de Antonio Quilis, Madrid: Editora Nacional, 1984 ( $2^{\mathrm{a}}$ ed.).

Paraíso, I.: Teoría del ritmo de la prosa. Barcelona: Planeta, 1976. -: El verso libre hispánico. Orígenes y corrientes. Madrid: Gredos, 1985.

Pelegrín, A. (2004), La aventura de oír. Cuentos tradicionales y literatura infantil. Madrid, Anaya, 2004.

Perona, J.: "Cambios fonéticos esporádicos: metaplasmos, vulgarismos o licencias fonológicas", en Estudios de Lingüística. Universidad de Alicante, 2002, no 16, pp. 5-36. http://rua.ua.es/dspace/bitstream/10045/6213/1/ EL 16 14.pdf.

Pozuelo Yvancos, J. M.. : Teoría del lenguaje literario. Madrid: Cátedra, 1988.

PujAnte, D.: Manual de retórica. Madrid: Castalia, 2003.

QuintiLIAno, Marco Fabio.: Institutionis oratoriae libri XII: Sobre la formación del orador, doce libros. Traducción y comentarios de Alfonso Ortega 
Carmona. Salamanca: Universidad Pontificia de Salamanca, 1997-2001, 5 vols.

Utrera Torremocha, M. a V.: Teoría del poema en prosa. Sevilla: Universidad de Sevilla, 1999.

-: Historia y teoría del verso libre. Sevilla: Padilla Libros, 2001.

VIVES, J. L.: El arte retórica. De ratione dicendi. Estudio introductorio de E.

Hidalgo-Serna; edición bilingüe, traducción y notas de A.I. CAMACHO. Barcelona: Anthropos, 1998.

YATES, F.: El arte de la memoria. Madrid: Taurus, 1974 [1966]. 